\title{
Conservation unit allows assessing vulnerability and setting conservation priorities for a Mediterranean endemic plant within the context of extreme urbanization
}

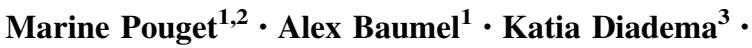 \\ Frédéric Médail ${ }^{1}$
}

\begin{abstract}
Current biodiversity patterns are a temporary state in a continuum of ecological and evolutionary changes. Conservation policies must incorporate this dynamic to ensure the long-term conservation of biodiversity which is particularly challenging in a context of extreme urbanization. An original approach, rarely used for plant conservation, is to define conservation units to set conservation priorities within species by combining ecological and evolutionary divergences. In the Maritime Alps (southern France), the ecological and evolutionary divergences between the populations of Acis nicaeensis has allowed us the determination of conservation units of this endemic plant threatened by severe urbanization and land-use changes. Phylogeographical data (cpDNA haplotype) were considered as a proxy for evolutionary legacy, and ecological data (multivariate analysis of habitat) were used as a proxy for ecological distinctiveness. Our goal was to explore the potential of this approach to assess vulnerability and set conservation priorities for narrow endemic species in the context of conflict between biodiversity and human activities. The results highlight five different conservation units within A. nicaeensis distribution. Genetic and ecological divergences are present at fine-scale. This pattern is highly endangered by urbanisation. This study highlights the vulnerability of conservation units near the coast whose
\end{abstract}

\section{Frédéric Médail}

Frederic.medail@imbe.fr

1 Institut Méditerranéen de Biodiversité et d'Ecologie marine et continentale (IMBE) Aix Marseille Université, CNRS, IRD, Univ. Avignon, Technopôle Arbois-Méditerranée Bât. Villemin - BP 80, F-13545 Aix-en-Provence cedex 04, France

2 Centre for Middle Eastern Plants, Royal Botanic Garden Edinburgh, 20a Inverleith Row, Edinburgh EH3 5LR, United Kingdom

3 Conservatoire botanique national méditerranéen de Porquerolles (CBNMed), 34 avenue Gambetta, 83400 Hyères, France 
originality and restricted distribution call for rapid conservation management to avoid the loss of species evolutionary and ecological distinctiveness.

Keywords Conservation priorities · Ecology $\cdot$ Endemism $\cdot$ Habitat fragmentation · Phylogeography $\cdot$ Vulnerability · Maritime Alps

\section{Introduction}

Faced with the challenge of reducing the loss of biodiversity, conservation biologists and ecologists strive to develop efficient strategies and methods for biodiversity conservation (Margules and Pressey 2000; Pärtel et al. 2005). Conservation biology aims to preserve current diversity and the ongoing diversification processes (Mace et al. 2003; Forest et al. 2007). Therefore, identifying spatial distribution of evolutionarily lineages is a priority to highlights geographic areas which have played an important role in the past in terms of emergence and persistence of biodiversity (Becerra and Venable 2008; Davis et al. 2008; Rosauer et al. 2009; Sauquet et al. 2009) and to ensure that the evolutionary legacy is recognized and protected (Moritz and Potter 2013).

The Evolutionarily Significant Unit (ESU) was conceptualized by Ryder (1986). Ryder (1986) defined an ESU as a population presenting significant adaptive variation based on concordance between sets of data related to life history information, morphometric, range and distribution, and genetic structure. The concept has since gained support, various definitions and criteria have been proposed (Ryder 1986; Waples 1991; Dizon et al. 1992; Moritz 1994; Vogler and DeSalle 1994; Crandall et al., 2000; Fraser and Bernatchez 2001). For Moritz (1994), the concept of ESU should be based upon historical biogeography rather than on adaptive diversity. The focus on evolutionary legacy is linked to the postulate that a set of populations, historically isolated and genetically different, are likely to be divergent lineages and will contribute to future diversification of the species (Moritz 1994, 2002). Therefore, according to Moritz (1994, 2002) and Moritz and Potter (2013) the function of the ESU is to prioritize conservation efforts according to an historic biogeographical structure (Davis et al. 2008; Kraft et al. 2010; Hendry et al. 2010, 2011; Isaac et al. 2007; Malaney and Cook 2013; Geeta et al. 2014). However, the use of the term ESU alone to set operational conservation units has been debated (Fraser and Bernatchez 2001; De Guia and Saitoh 2007). Crandall et al. (2000) suggested focusing on the identification of distinct populations through ecological and genetic exchangeability tests over historical and recent times. Exchangeability, in essence, means that populations are replaceable, which means that these replaceable populations are lower in population prioritization with regard to conservation.

This theoretical debate appeared far from the reality of conservation issues (Fraser and Bernatchez 2001). It appeared indeed that ESU-related research papers are rarely used to improve conservation policies or assess threats to biodiversity (Lopez et al. 2015). Furthermore the concept of the ESU has been used almost exclusively for mammals or birds species (De Guia and Saitoh 2007) but it has almost never been used for plants (Newton et al. 1999; Lopez et al. 2015).

Here, we are attempting to examine an approach related to the ESU concept to delineate conservation units and set conservation priorities for a Mediterranean narrow endemic plant. Mediterranean plant populations are the results of long term accumulation of 
diversity in very heterogeneous landscapes leading eventually to a strong evolutionary legacy on a very fine scale (Thompson et al. 2005; Médail and Diadema 2009; Pouget et al. 2013). Today, this legacy is endangered by severe anthropogenic pressures (e.g. Blondel and Médail 2009), especially in lowland areas and near the coasts where urbanization is increasing at an unprecedented rate of $+17 \%$ from 1990 to 2000 (Underwood et al. 2009). In this context, we combined phylogeographical data considered as a proxy for evolutionary legacy, to ecological data, used as a proxy for ecological distinctiveness, to define conservation units and to set conservation priorities. We apply this approach to delineate conservation units within the rare geophyte plant species Acis nicaeensis (Ardoino) Lledó, A.P. Davis and M.B. Crespo (Amaryllidaceae), an endangered narrow endemic, restricted to a small area in the Maritime Alps, including the major cities of Nice and Monaco within the severely impacted French Riviera (Diadema et al. 2007).

The objectives of this study are (i) to infer the phylogeography of A. nicaeensis from the distribution of maternal lineages in twenty two populations (ii) which will be combined with ecological distinctiveness of populations, (iii) to delineate conservation units and then to assess the vulnerability of each unit in relation with urban sprawl.

\section{Materials and methods}

\section{Study system}

The studied species is the Nice's snowflake A. nicaeensis, a narrow endemic geophyte plant from the southern part of the Maritime Alps, with a patchy distribution on calcareous rocky grasslands. The distribution of A. nicaeensis covers approximately $12 \times 35 \mathrm{~km}$ between the Pre-Alps of Grasse (col de Vence) to the west, and the only Italian population near the French-Italian border (Grimaldi, Ventimiglia) to the east. The highest population densities are found between Nice and Menton with c. 50 patches or populations. The delimitation of populations is described below ("Assessment of vulnerability (or threats)" section). This snowflake has quite a large ecological amplitude, and the three main habitats of A. nicaeensis are structured along an altitudinal gradient from sea level to mid-altitude mountains: (i) a thermophilous matorral ( $n=19$ populations) with Euphorbia dendroides, Arisarum vulgare, Brachypodium retusum, Asparagus acutifolius and Smilax aspera evolving towards a thermo-Mediterranean pre-forest with Pinus halepensis and Quercus ilex; (ii) a mid-altitude situation ( $n=11$ populations), characterized, more or less, by disturbed xerophytic grassland with annual species and the presence of several ruderal perennial plants (Artemisia verlotiorum, Centaurea paniculata, and Lobularia maritima); (iii) a higher altitude $(600-1000 \mathrm{~m})$ xerophytic grasslands with perennial species (Bromus sp., Lavandula angustifolia, Genista hispanica, $n=17$ ) on limestone rocks (Diadema et al. 2007; Noble and Diadema 2011). During the early XXth century, some populations of $A$. nicaeensis were severely damaged by massive sampling for herbarium collections and several populations have disappeared since the middle of the XXth century as a result of urbanization and land use changes (Diadema et al. 2007). Several factors are threatening this species, including the spatial increase of trees and shrubs covers induced by the collapse of traditional land-use, and above all the huge development of urbanization along the Riviera coast and the increase of tourism related activities (Diadema 2006). For these reasons this snowflake is recorded in the annexes II and IV of the European Habitats 
(a)

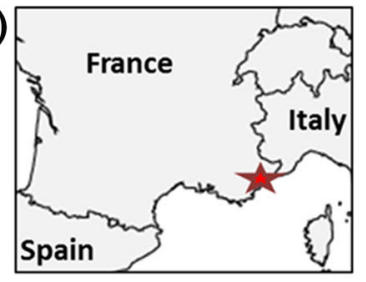

(b)

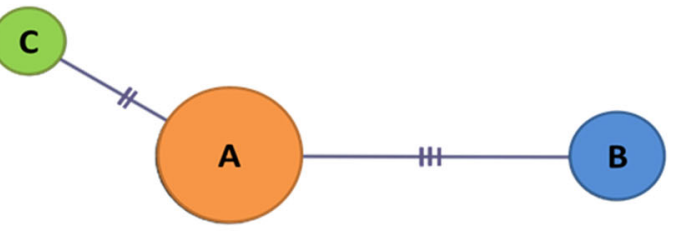

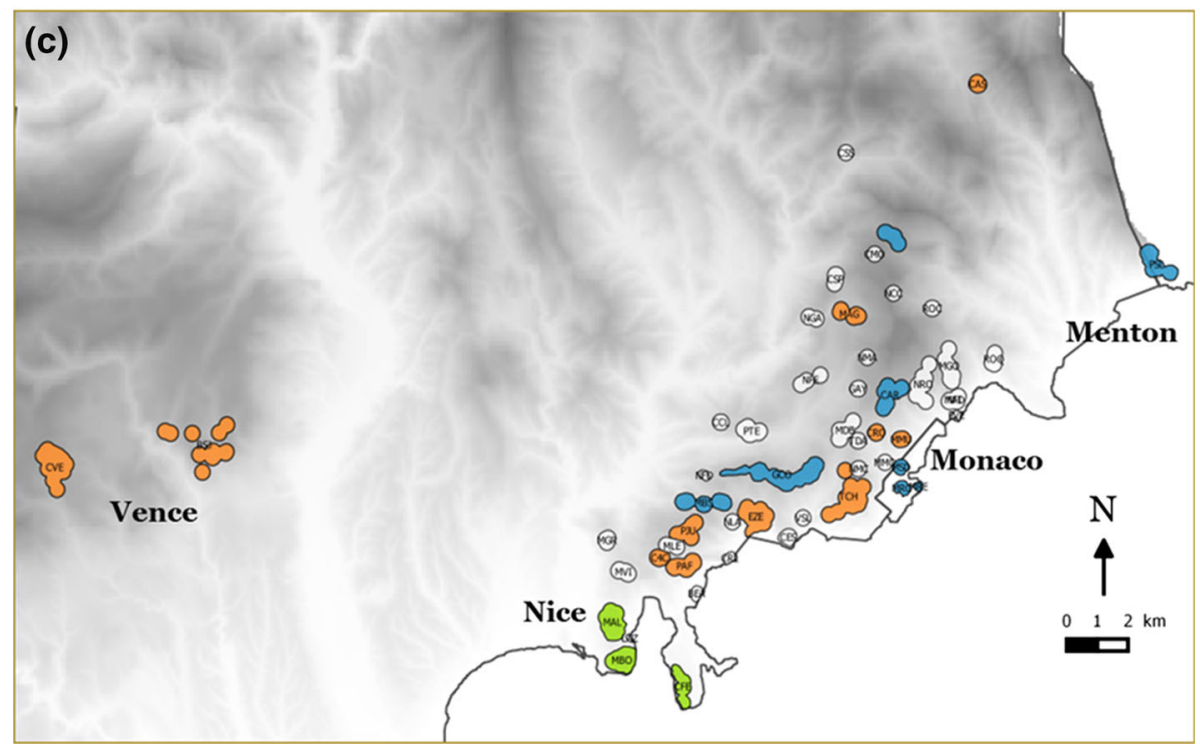

Fig. 1 a Location of the study site (red star); b network of the three cpDNA haplotypes detected for the 63 individuals of A. nicaeensis by combining the polymorphisms of five loci. Each haplotype is associated with a colour and a sphere size proportional to the number of individuals. Two mutations were observed between $A$ and $C$, three between $A$ and $B$; $\mathbf{c}$ distribution of the three cpDNA haplotypes among the A. nicaeensis populations. Populations without genetic information are indicated in white. (Color figure online)

Directive, and included in the 'Livre rouge de la flore menacée de France, espèces prioritaires' (Olivier et al. 1995).

\section{Sampling, DNA extraction and sequence analysis}

The study area is bounded by the distribution range limit of A. nicaeensis. Twenty-two populations were sampled throughout their entire geographical range in April 2012 (see Fig. 1). Leaves were dried with silica gel and then stored at $-20{ }^{\circ} \mathrm{C}$. Total DNA extraction is following the CTAB protocol of Doyle and Doyle (1987). The polymorphism of the chloroplast genome was investigated in one to three randomly sampled individuals per population $(\mathrm{n}=63)$ on five plastid regions: the internal part of the matK gene; $\operatorname{trnL}-\operatorname{trn} F$, trnT-trnL and trnT-trnD intergenic spacer, trnH intron plus $5^{\prime}$ part psbA (abbreviate respectively matK, LF, TL, TD and psba). PCRs were performed in a $50 \mu$ l volume reaction that contained $2 \mu \mathrm{l}$ of each primer $(5 \mathrm{mM}), 1.25$ units of Taq polymerase (QBiogen), $5 \mu \mathrm{l}$ of incubation buffer, $6 \mu \mathrm{l}$ of $\mathrm{MgCl} 2(10 \mathrm{mM}), 4 \mu \mathrm{l}$ of dNTP $(25 \mathrm{mM})$ and $5 \mu \mathrm{l}$ of DNA (50 ng/ $\mu \mathrm{l})$. Amplification was performed using a PTC-200 thermocycler (MJ Research). Direct sequencing (ABI 3730 xl, Applied Biosystems) was carried out by 
Eurofins sequencing services (Germany). After quality checking and alignment, the cpDNA data set contained 63 sequences.

\section{Phylogenetic and ecological distinctiveness to delineate conservation units}

A median-joining network (Bandelt et al. 1999) has been constructed using SplitsTree4 software (Huson and Bryant 2006) including both substitution and insertion/deletion (indel). Indels sites were reduced, considered as a fifth state and weighted as a substitution.

Twenty-one populations of A. nicaeensis were surveyed for environmental and vegetation characteristics (Conservatoire Botanique National Méditerranéen de Porquerolles (CBNMed) and Conservatoire Botanique National Alpin (CBNA) (2015). SILENEHabitats. http://habitats.silene.eu), since the twenty-second population was destructed by urbanisation. Relevés were performed on $100 \mathrm{~m}^{2}$ homogeneous vegetation. For each relevé, 15 environmental and ecological variables were taken into account: average annual temperature (worldclim data base), average annual precipitation (worldclim data base), altitude, exposition, slope, proportion of naked ground, pebbles, rocks and blocks, proportion of cover by herbaceous plants, by small shrubs $(<1 \mathrm{~m})$, by high shrubs (between 1 and $4 \mathrm{~m})$, by low trees $(10 \mathrm{~m})$ and by high trees $(>10 \mathrm{~m})$, as well as the total vegetation cover (RcvtTotal). A principal component analysis (PCA function "dudi.pca", package "ade4", R core team 2015) has been built for the 15 mesologic and environmental variables. Then ecological groups were delineated by a kmeans classification (function "kmeans", R core team 2015) based on PCA component coordinates of each relevés to set groups of relevés that describe comprehensively the two first PCA components. On the basis of our knowledge a design according to three ecological groups was better to describe the habitat diversity of A. nicaeensis than with two or more. Kmeans method was performed on PCA components rather than on raw data to avoid bias due to variable collinearity.

Finally, each cpDNA haplotype was considered as a distinct evolutionary group. Ecological groups have been merged with haplotypes information in order to delineate conservation units. Both information were considered as equal, two populations being assigned to the same conservation unit if bearing the same haplotype and living in the same ecological group. The map representing the different elements (haplotypes, ecological groups and conservation units) has been displayed using the GIS software QGIS (QGIS Development Team 2015).

\section{Assessment of vulnerability (or threats)}

Several field trips were conducted for the data collection of 662 points of occurrence of $A$. nicaeensis, databased in SILENE-Flore (http://flore.silene.eu; CBNMed and CBNA 2015). They have been grouped by location, for a total of 52 populations. The delimitation of populations is based on net geographical discontinuities between the occurrences (more than $500 \mathrm{~m}$ around occurrence). Most of the population structures have been extracted from the thesis of Diadema (2006) and completed by several field trips (Diadema and Médail from 2007 to 2014). For each population studied, the total number of individuals observed has been counted. The minimum and maximum number of individual per population is recorded for each conservation units (Table 1). Population areas have been calculated as the surface of a polygon including the area of the population in two dimensions (altitude has not been taken into account) using the GIS software QGIS (QGIS 
Table 1 Summary of population characteristics and main threats for each conservation unit of A. nicaeensis

\begin{tabular}{|c|c|c|c|c|c|c|}
\hline \multirow{2}{*}{\multicolumn{2}{|c|}{$\begin{array}{l}\text { Range size } \\
\text { Area sum } \\
\left(\mathrm{km}^{2}\right)\end{array}$}} & \multicolumn{3}{|c|}{ Populations } & \multicolumn{2}{|l|}{ Threats } \\
\hline & & $\begin{array}{l}\mathrm{Nb} \\
\mathrm{pop}\end{array}$ & $\begin{array}{l}\mathrm{Nb} \text { indiv/ } \\
\text { pop }\end{array}$ & Isolation & $\begin{array}{l}\text { Urbanisation } \\
(\%)\end{array}$ & Main threats \\
\hline AA & 4.672 & 6 & $31-2000$ & 8.45 & 28.3 & $\begin{array}{l}\text { Low to urbanisation, high to land-use } \\
\text { change }\end{array}$ \\
\hline BA & 4.266 & 5 & $85-414$ & 9.59 & 21.0 & $\begin{array}{l}\text { Low to urbanisation, high to land-use } \\
\text { change }\end{array}$ \\
\hline $\mathrm{AC}$ & 3.366 & 5 & $148-460$ & 8.08 & 40.3 & $\begin{array}{l}\text { At the margin of major city, high } \\
\text { disturbance }\end{array}$ \\
\hline $\mathrm{BB}$ & 0.252 & 2 & $10-50$ & 8.37 & 92.5 & $\begin{array}{l}\text { High to urbanisation, high } \\
\text { competition with exotic }\end{array}$ \\
\hline $\mathrm{CB}$ & 1.947 & 3 & $2-94$ & 7.93 & 48.3 & $\begin{array}{l}\text { High to urbanisation, high } \\
\text { competition with exotic }\end{array}$ \\
\hline
\end{tabular}

Development Team 2015). Conservation unit range size, calculated as the area of the unit, is the sum of all populations' superficies in $\mathrm{km}^{2}$ (Table 1).

The isolation of the conservation units represents the mean distance separating the population of the unit from all the others population. The distance is calculated using the centroid of the population and the function "rdist.earth" (package "fields", R core team 2015). The value is given in $\mathrm{km}$.

Because the main threat for A. nicaeensis is the urban sprawl along the Riviera coast (Diadema 2006) we quantified it, other threats are existing but they are more spatially restricted and they will be discussed.

As a proxy of A. nicaeensis threats, the actual urbanization cover has been estimated per conservation unit using the IGN (National Institute of Geography, France) map of 2006. It has been included inside the category "urbanization" all possible artificialized structures such as, buildings of all types, sport centres and fields, roads, staircases, parking, water tank, etc. But the use of the IGN map systematically underestimates our perception of the artificialisation by masking some features (like pedestrian road, artificial green area, forest plantation, etc.). A percentage of urbanization cover has been given for every $10,000 \mathrm{~m}^{2}$ mesh. The mesh size was defined in order to facilitate the visual assessment of the urbanization and to allow for the following spatial analysis (using the GIS software QGIS). $0 \%$ represents no urbanization at all, $100 \%$ representing a strictly urbanized mesh. The final percentage value of a unit is the mean percent of all meshes that intersect the populations of a conservation unit (Table 1).

\section{Results}

\section{Phylogeography as a proxy of evolutionary legacy}

The molecular study of A. nicaeensis based on five cpDNA spacers (matK, LF, TL, TD and psba), giving a combined sequence length of $3797 \mathrm{bp}$, revealed five polymorphic sites (three substitutions and three indels) with the presence of three haplotypes (Fig. 1a), all 
well supported by at least one substitution and one indel. MatK presents two substitutions, LF presents one indel, TL presents one substitution, and psba presents two indels (Genbank accession number: Haplotype A: KX018277, KX018280, KX018282, KX018284, KX018285; Haplotype B: KX018278, KX018281, KX018283, KX018284, KX018286; Haplotype C: KX018279, KX018280, KX018282, KX018284, KX018287). Up to three individuals per population has been sampled to verify the monotypic identity of population. No diversity has been found within populations. Each cpDNA haplotype was considered as a distinct evolutionary unit. The haplotype A occurs from the West (CVE, col de Vence) to the East (CAS, Castillon) of A. nicaeensis the distribution (Fig. 1b). The haplotype B is present in seven studied populations and is mainly distributed in the central and eastern
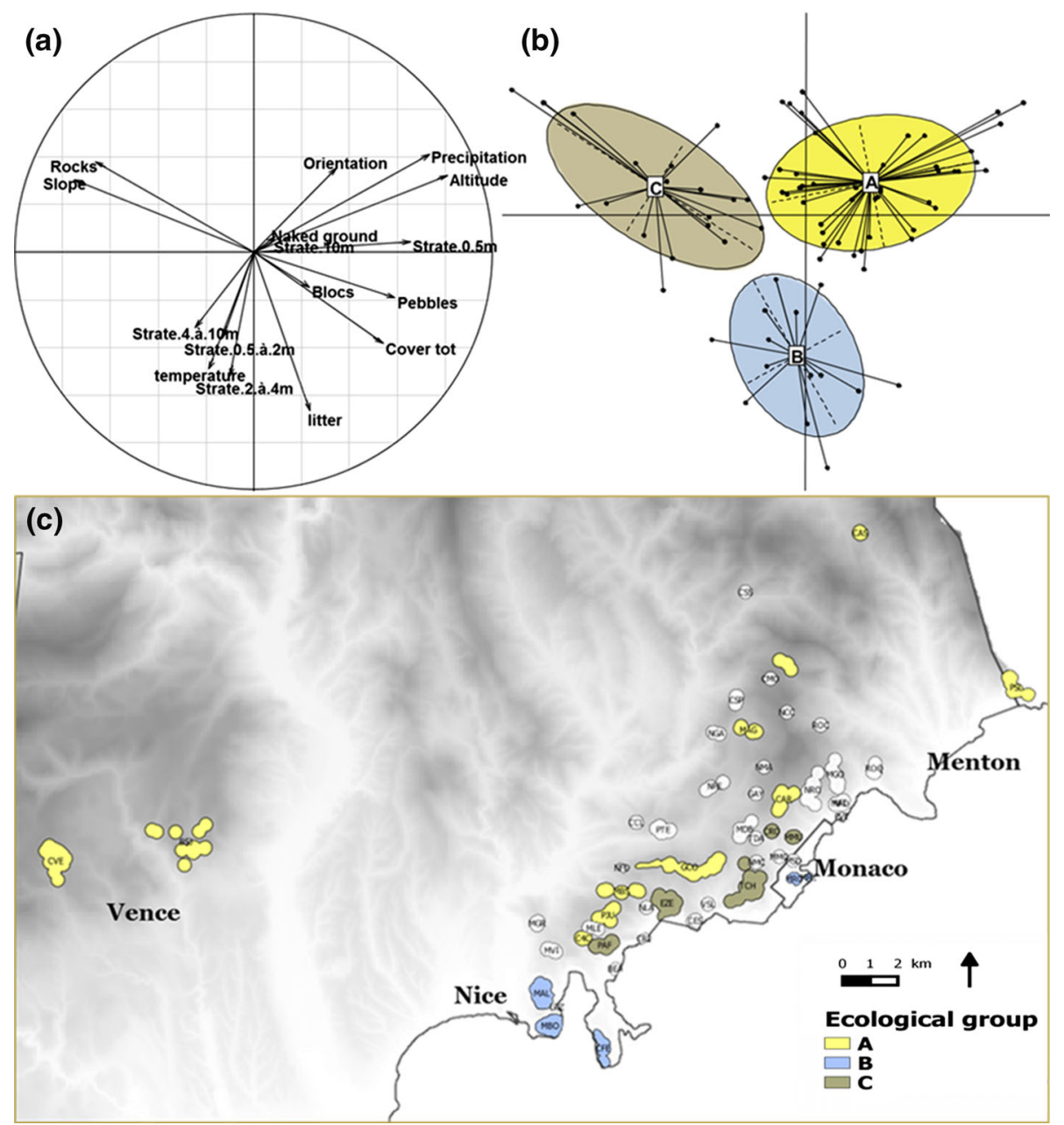

Fig. 2 Ecological distinctiveness of A. nicaeensis populations based on habitat variables assessed by field relevés and climatic data. a Principal components analysis (PCA) of the 21 studied populations of $A$. nicaeensis, showing the importance of each variable within the scattergram delimited by the axis 1 and 2 . b Structure and distribution of the three ecological groups obtained by a kmean clustering method applied to PCA coordinates of populations. c Geographical distribution of the three ecological groups among the $A$. nicaeensis populations ( $A$ in yellow $B$ in blue and $C$ in light brown). (Color figure online) 
parts of the distribution. The haplotype $\mathrm{C}$ is the most restricted as it occurs only in the south-western part of the distribution, near Nice and the Cap-Ferrat peninsula, including only three populations (Fig. 1b).

\section{Multivariate analysis of habitat as a proxy of ecological distinctiveness}

Environmental and vegetation data characterizing the 21 relevés allow the distinction of 3 main ecological groups for A. nicaeensis (Fig. 2a, b), with the two main axes of the ACP representing $35 \%$ of inertia.

The first group (A) corresponds to the rocky lawns populations growing in the highest altitude (e.g. the population of Castillon CAS or Col de Vence CVE), with a high cover of low shrubs (e.g. Thymus vulgaris, Euphorbia spinosa) or herbaceous species and a reduced cover of high trees and shrubs. This group of relevés is typical of the meso-Mediterranean vegetation belt in the Maritime Alps (Noble and Diadema 2011). It is mainly located in the northern range of the distribution, with the largest range from east to west of the distribution, between altitudes $400 \mathrm{~m}$ and $960 \mathrm{~m}$ a.s.l. (Fig. 2c). The second and third groups of relevés are located within the thermo-Mediterranean vegetation belt, defined by several thermophilous plant species. The second group (B) represents populations growing on habitats with a high percentage of rock cover and high slope; it corresponds to rocky crevice and steep scree habitats, characterized by rocky dry lawns with Brachypodium retusum associated with annual and bulbous plants such as Allium acutiflorum. The B group encompasses populations occurring in the centre of the distribution, from $250 \mathrm{~m}$ of altitude to around $500 \mathrm{~m}$ a.s.l. The third group (C) includes populations whose habitat is determined by a quite important cover of high trees, shrubs and litter. It corresponds to the coastal thermophilous matorral with Euphorbia dendroides, Pistacia lentiscus, Olea europaea subsp. europaea and Ceratonia siliqua. This ecological group is located close to the coast in two areas (Nice, Cap-Ferrat and Monaco), from $10 \mathrm{~m}$ altitude to less than $200 \mathrm{~m}$ a.s.1.

\section{Delimitation of the conservation units and assessment of vulnerability}

Phylogenetic and ecological data have been merged to delineate the conservation units. Both data were considered as equal, two populations being assigned to the same conservation unit if bearing the same haplotype and living in the same ecological group. Among the nine possible combinations between phylogenetic and ecological data, five units were observed and distinguished as conservation units for A. nicaeensis. They have been named firstly by the haplotype number, then by ecological group, accordingly AA, AC, BA, BB and $\mathrm{CB}$ units. There is a large difference between units in terms of spatial isolation and geographical distribution of populations (Fig. 3), but also in term of size (range size or individual number) and urbanisation threats (Table 1). It is interesting to note that the most geographically isolated populations (such as CVE and PSL, respectively the westernmost and easternmost populations) are included in conservation units that are also present in the centre of the species distribution (AA and BA) (Table 1). These latter units exhibit the largest distributions, the largest range size but also a lower level of urbanisation cover. The AC units possess a smaller distribution in the southern range but with equivalent number of populations than BA (5 populations) and a low isolation. These units include the largest populations of $A$. nicaeensis in terms of individual number. The $\mathrm{CB}$ and $\mathrm{BB}$ units are the smallest ones in terms of distribution range and number of populations (respectively only three and two populations), a very restricted range size especially for the BB unit restricted 


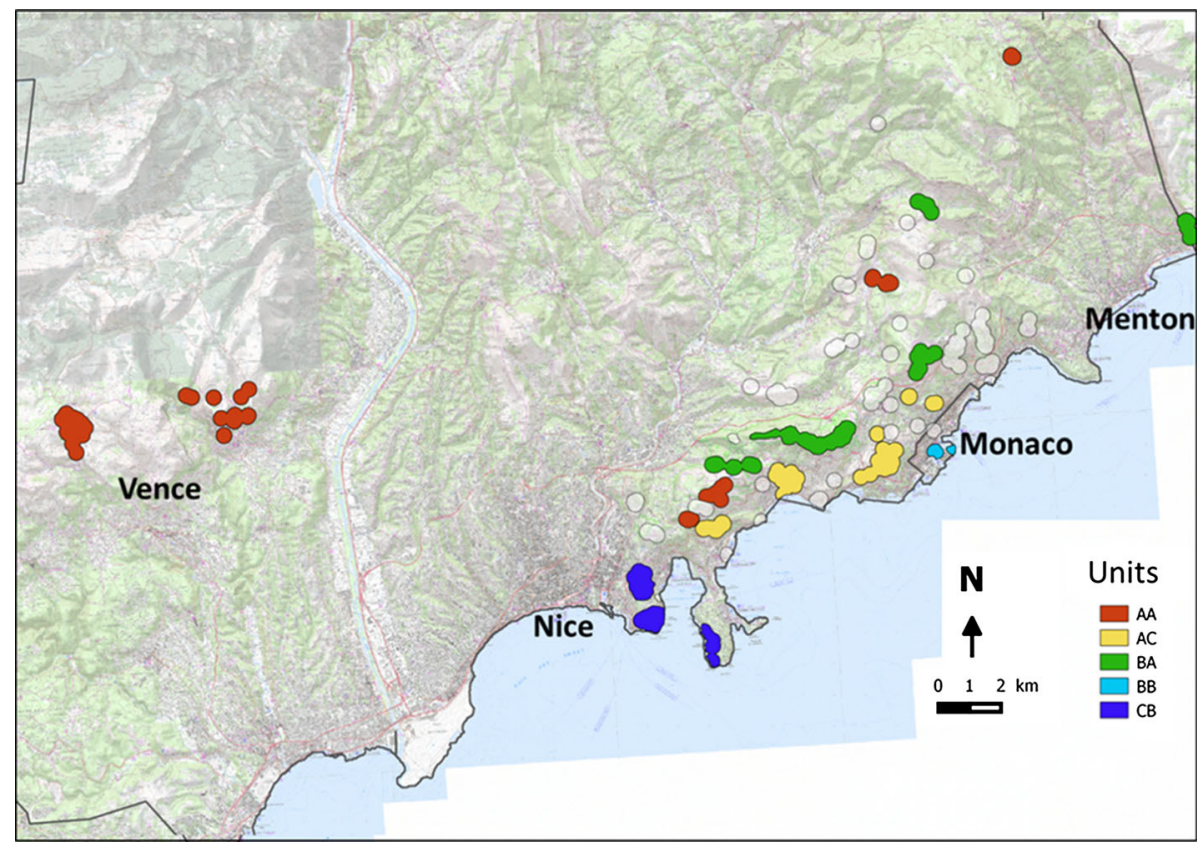

Fig. 3 Distribution of the five conservation units among the A. nicaeensis populations. Conservation units are designed according to their cpDNA haplotype (first letter, cf. Fig. 2) and then to their ecological group (second letter). (Color figure online)

to Monaco, and have very few individuals per population. These two units are included in the same ecological group, and the CB represents by itself one single haplotype revealing a unique evolutionary distinctiveness. These last two units are also the most threatened, because of a very high proportion of urban cover and the lowest number of individuals per population (Table 1).

\section{Discussion}

\section{Assessment of evolutionary and ecological distinctiveness}

In the context of an extreme environmental change induced by urbanization (Araújo 2003; Aronson et al. 2014; McCleery et al. 2014) protected species or habitats are continuously being degraded along the Mediterranean coastline (Sirami et al. 2010; Lhotte et al. 2014). The consequence is an extreme fragmentation of populations, which persist in patchy and highly urbanised areas (McKinney 2002; Fahrig 2003). To limit the vulnerability of the populations, it is essential to define conservation units for the rarest and most endangered plant species, notably the endemics species located in areas of high urban sprawl. The French Riviera represents unfortunately an "emblematic case" of this worrying socioecological trend where refugial areas of unique biodiversity are threatened by direct human impact (Médail and Diadema 2006). It is therefore important to preserve the evolutionary legacy of narrow endemics like A. nicaeensis whose populations were moulded by the 
complex historical biogeography of the Maritime Alps hotspot (Médail and Verlaque 1997; Casazza et al. 2008).

Our approach is based on a heuristic comparative analysis, able to gather information from various sources and quality. It is essential to establish a fast diagnostic and to provide strong arguments to help conservationists to focus their actions in the field. Our study detected five conservation units within A. nicaeensis by using simple molecular tools (PCR and direct Sanger sequencing for a total cost $<1000 €$ ) combined with analysis of habitat structure and threats. Our capacity to design discrete conservation units in the case of $A$. nicaeensis is particularly valuable because (i) these units are under different pressures of urban sprawl and (ii) their loss would severely decrease the intraspecific diversity of $A$. nicaeensis.

Three haplotypes are found among the populations of A. nicaeensis, and this genetic structure is well structured and supported despite the very restricted distribution range of the species. Variation from cpDNA genome, maternally inherited in Angiosperm, is highly affected by demographic history (Avise 2000). Studying the demographic history through phylogeography is crucial to identify geographic areas having played a role in terms of persistence or migration of populations (Avise 2009; Hewitt 2000). CpDNA markers often present a lack of variation (Schaal et al. 1998), but several recent studies revealed that it is not always the case for Mediterranean plants (e.g. Molins et al. 2011; Migliore et al. 2011; 2012; Mayol et al. 2012; Pouget et al. 2013). The phylogeographic data is structured and supported. This information is relevant from the historical perspective and can help to preserve the lineages and biogeographical pattern of the species (Ladle and Whittaker 2011).

These three haplotypes differ in terms of spatial distribution and abundance (Fig. 1). The first conservation issue is that haplotype $\mathrm{C}$ is restricted to a small area neighbouring Nice city in the southern part of the distribution, the second issue is the presence of the three haplotypes in the fringe coastal zone. The coastal and low altitude populations are therefore crucial for the preservation of the evolutionary legacy of A. nicaeensis. In parallel, multivariate analysis of habitat as a proxy of ecological distinctiveness highlight the ecological originality of the coastal area: the ecological group $\mathrm{C}$ is narrowly restricted to the thermophilous matorral distributed from sea level to $200 \mathrm{~m}$ a.s.l., and its area of occupancy is very close to, or within major cities of the coast (Nice and Monaco-city). Two ecological groups are present near the coast, so, two-thirds of the ecological diversity of $A$. nicaeensis population is situated near the coastline. The coastal fringe exhibits most of the biogeographical originality of this plant as it encompasses geographically restricted ecological groups and unique evolutionary legacy.

\section{Delineation of conservation units allows us to summarise threats}

The use of both genetic and ecological information to delineate conservation units has rarely been done among plant species (e1.g. Lopez et al. 2015). This lack of studies is quite surprising because it denies the consideration of evolutionary legacy in conservation. Our results demonstrate that endemic species, even with extremely narrow ranges, can contain multiple conservation units, they are potentially genetically diverse and range along ecological gradients (e.g. Pouget et al. 2013).

Three main results are emerging from the delineation of the conservation units. One major result is the presence of different units separated by short distances (Fig. 3), a second one is that by combining the two types of information it emphasized the role of the coastal fringe from where two conservation units are very restricted; one around Nice (CB) and 
one in Monaco (BB). The third result is that gathering populations in conservation units allows us to assess information about threats and enables us to summarize them (Table 1).

AA and BA conservation units cover large areas with populations often outnumbering 100 individuals, but they contains the more isolated populations, these are mainly threatened by land-use changes (see Diadema et al. 2006), i.e. land-abandonment due to the collapse of agro-sylvo-pastoral practices (see Tatoni et al. 2004; San Roman Sanz et al. 2013; Otero et al. 2015) but not by urbanization. Indeed they present low urbanisation cover (Table 1). The AC conservation unit represents an intermediary situation which stretches along an important area at the margin of the major cities of Nice and Monaco. As a consequence $\mathrm{AC}$ units are under high disturbance pressure, easily seen in the field (trampling, paths, waste and ruderalisation) and its populations are close to areas of ongoing urban sprawl (and a urban cover 40\%, Table 1). Most of the populations of AA, $\mathrm{BA}$ and AC conservation units are exempt from direct, major threats, but regular monitoring of AC unit populations is necessary in order to estimate their dynamic trends.

As human population continue to grow, urban areas will continue to expand (Meyer and Turner 1992; Médail and Diadema 2006; Underwood et al. 2009). The regression of the "natural habitats" due to urban sprawl constitutes a major threat to biodiversity worldwide (Wilcove et al. 1998; Chapin et al. 2000; McDonald et al. 2008) and particularly in the Mediterranean area and the French Riviera (Hoekstra et al. 2005; Médail and Diadema 2006; Cuttelod et al. 2008). Furthermore, the urban ecological footprint extends beyond city boundaries and drives environmental change at local to global scales (Grimm et al. 2008). Indeed, urban areas are threatening ecosystems through both direct habitat conversion (Clergeau 1998; McKinney 2002) and various indirect effects, e.g. land use change in the periphery of urban areas, fragmentation by linear infrastructures such as transport road among urban areas, waste generation, water pollution, disturbances associated with recreational activities (DeFries et al. 2007). In some areas, such as the coast of the French Riviera, there is a strong probability of invasion by exotic species, also linked to human pressures. In our case, the threats caused by major plant invasions (Opuntia div. sp. or Freesia alba) jeopardize the future of these snowflake populations (Diadema et al. 2007).

Thus, the CB unit (near Nice and cap Ferrat) and BB unit (within the Principaute de Monaco) are in imminent danger of extinction. They represent unique evolutionary lineages and ecological group that make them original, but at the same time they present a restricted range, a small number of populations and a low number of individuals per population (Table 1). All these combined features make them highly vulnerable. These units are threatened by a very high level of urbanization as in BB (Monaco) with more than $90 \%$ of urban cover, and this unit occurs within one of the most populated area of the world $\left(16,000\right.$ inhabitant per $\left.\mathrm{km}^{2}\right)$. It is not surprising that the population of Monaco St-Devote (MSD) became extinct in situ in 2006 (CBNMED/IMBE unpubl., Pouget 2014). Moreover the areas of these units $(\mathrm{CB}$ and $\mathrm{BB})$ are not included in a high level protection area; sensu IUCN such as a nature reserve or national park (Dudley 2008; Lefebvre and Moncorps 2010). Even if management priorities are currently directed toward in situ conservation, ex situ conservation should also be required, to restore or reinforce populations of BB and CB conservation units. Indeed, at least 10 years monitoring, (Diadema and Médail, unpublished data) shows that the demographic regeneration is limited and a probable extinction of these units should not be excluded. 


\section{Conclusions}

In most cases characterized by intensive human impacts, there is no choice but to accept the challenge of managing the future of the local biodiversity in extreme urbanization area. Overall, the results of this study highlight the vulnerability of units near the coast whose originality and restricted distribution call for rapid conservation management to avoid the loss of an evolutionary legacy. The presence of different units within a species has direct implication for the management of the species, for instance in suggesting a sampling strategy for an efficient ex situ conservation sampling (e.g. Ferguson et al. 1998), or in deciding which populations should be enhanced and/or preserved (e.g. Fischer et al. 2000). Another interesting perspective in the case of severe habitat fragmentation and urbanization, but also strong floristic diversity, would be to target conservation action on a network of small areas. In the Mediterranean region, the Plant Micro-Reserves network (PMR) represents a valuable practical conservation framework supported by the European Union (Laguna et al. 2004; Lumbreras 2001; Kadis et al. 2013). This approach, first tested in Spain and then extended to other Mediterranean areas (Cyprus, Crete, Croatia), seems promising, especially because it allows closer monitoring of the most endangered plant populations, implementing action, appropriate to the particular needs of species.

Acknowledgements This research was part of the Ph.D. thesis of Marine Pouget supported by the Région Provence-Alpes-Côte d'Azur (PACA) and performed at the IMBE/Aix-Marseille University. Molecular screening was realized by the molecular biology service of IMBE and we thanks Nathalie Duong for her help. For their great contribution in the record of Acis nicaeensis populations, we would like to thanks Julien Baret (BIODIV) and Jérôme Volant (ECOMED). Field and molecular works were partly funded by the Prince's Government of the Principality of Monaco (Department of the Environment), the Prince Albert II of Monaco Foundation (project MONACOBIODIV) and the Provence-Alpes-Côte d'Azur regional environmental management centre (DREAL-PACA).

\section{References}

Araújo MB (2003) The coincidence of people and biodiversity in Europe. Glob Ecol Biogeogr 12:5-12 Aronson MFJ, La Sorte FA, Nilon CH, Katti M, Goddard MA, Lepczyk CA, Warren PS, Williams NSG, Cilliers S, Clarkson B, Dobbs C, Dolan R, Hedblom M, Klotz S, Kooijmans JL, Kuhn I, Macgregorfors I, Mcdonnell M, Mörtberg U, Pysek P, Siebert S, Werner P, Winter M, Aronson MFJ, La Sorte FA, Nilon CH, Katti M, Goddard MA, Lepczyk CA, Warren PS, Williams SG, Cilliers S, Clarkson B, Dobbs C, Siebert S, Sushinsky J, Werner P, Winter M (2014) A global analysis of the impacts of urbanization on bird and plant diversity reveals key anthropogenic drivers A global analysis of the impacts of urbanization on bird and plant diversity reveals key anthropogenic drivers. Proc R Soc B Biol Sci 281:20133330

Avise JC (2000) Phylogeography: the history and formation of species. Harvard University Press, Cambridge Avise JC (2009) Phylogeography: retrospect and prospect. J Biogeogr 36:3-15

Bandelt HJ, Forster P, Röhl A (1999) Median-joining networks for inferring intraspecific phylogenies. Mol Biol Evol 16:37-48

Becerra JX, Venable DL (2008) Sources and sinks of diversification and conservation priorities for the Mexican tropical dry forest. PLoS ONE 3:e3436

Blondel J, Médail F (2009) Biodiversity and conservation. In: Woodward JC (ed) The physical geography of the Mediterranean. Oxford University Press, Oxford, pp 615-650

Casazza G, Borghesi B, Roccotiello E, Minuto L (2008) Dispersal mechanisms in some representatives of the genus Moehringia L. (Caryophyllaceae). Acta Oecol 33:246-252

Chapin FS, Zavaleta ES, Eviner VT, Naylor RL, Vitousek PM, Reynolds HL, Hooper DU, Lavorel S, Sala OE, Hobbie SE, Mack MC, Díaz S (2000) Consequences of changing biodiversity. Nature 405:234-242

Clergeau P (1998) Biodiversite dans les paysages urbains: des concepts aux applications. Penn ar Bed 165-166:13-17 
Crandall KA, Bininda-Emonds ORP, Mace GM, Wayne RK (2000) Considering evolutionary processes in conservation biology. TREE 15:290-295

Cuttelod A, García N, Malak DA, Temple H (2008) The mediterranean: a biodiversity hotspot under threat. In: Vié JC, Hilton-Taylor C, Stuart SN (eds) The 2008 review of The IUCN red list of threatened species. IUCN, Gland

Davis EB, Koo MS, Conroy C, Patton JL, Moritz CC (2008) The California Hotspots Project: identifying regions of rapid diversification of mammals. Mol Ecol 17:120-138

De Guia APO, Saitoh T (2007) The gap between the concept and definitions in the Evolutionarily Significant Unit: the need to integrate neutral genetic variation and adaptive variation. Ecol Res 22:604-612

DeFries R, Hansen A, Turner BL, Reid R, Liu J (2007) Land use change around protected areas: management to balance human needs and ecological function. Ecol Appl 17:1031-1038

Diadema K (2006) Apport de la phylogéographie, de la dynamique et de la structure des populations pour la conservation des végétaux endémiques méditerranéens. PhD Thesis, Université Paul Cézanne AixMarseille, Marseille

Diadema K, Médail F, Castagné H, Affre L, Roux JP, Bretagnolle F (2007) Ecologie, distribution et morphologie comparées des nivéoles de Nice (Acis nicaeensis) et de Fabre (Acis fabrei), Alliaceae endémiques des Alpes maritimes et de la Nesque (Vaucluse). Acta Bot GALLICA 154:619-634

Dizon AE, Lockyer C, Perrin WF, Demaster DP, Sisson J (1992) Rethinking the stock concept: a phylogeographic apporach. Conserv Biol 6:24-36

Doyle JJ, Doyle JL (1987) A rapid DNA isolation procedure for small quantities of fresh leaf tissue. Phytochem Bull 19:11-15

Dudley N (2008) Guidelines for applying protected area management categories. In: Stolton S, Shadie P, Dudley N (eds) IUCN WCPA best practice guidance on recognising protected areas and assigning management categories and governance types, best practice protected area guidelines series No. 21. IUCN, Gland

Fahrig L (2003) Effects of habitat fragmentation on biodiversity. Annu Rev Ecol Syst 34:487-515

Ferguson ME, Ford-Lloyd BV, Robertson L, Maxted N, Newbury HJ (1998) Mapping the geographical distribution of genetic variation in the genus Lens for the enhanced conservation of plant genetic diversity. Mol Ecol 7:1743-1755

Fischer M, Van Kleunen M, Schmid B (2000) Genetic Allee effects on performance, plasticity and developmental stability in a clonal plant. Ecol Lett 3(6):530-539

Forest F, Grenyer R, Rouget M, Davies TJ, Cowling RM, Faith DP, Balmford A, Manning JC, Procheş S, van der Bank M, Reeves G, Hedderson TA, Savolainen V (2007) Preserving the evolutionary potential of floras in biodiversity hotspots. Nature 445:757-760

Fraser DJ, Bernatchez L (2001) Adaptive evolutionary conservation: towards a unified concept for defining conservation units. Mol Ecol 10:2741-2752

Geeta R, Lohmann LG, Magallon S, Faith DP, Hendry A, Crandall K, De Meester L, Webb C, PrieurRichard AH, Mimura M, Conti E, Cracraft J, Forest F, Jaramillo C, Donoghue M, Yahara T (2014) Biodiversity only makes sense in the light of evolution. J Biosci 39:333-337

Grimm NB, Faeth SH, Golubiewski NE, Redman CL, Wu J, Bai X, Briggs JM (2008) Global change and the ecology of cities global change and the ecology of cities. Science 319:756-760

Hendry AP, Lohmann LG, Conti E, Cracraft J, Crandall KA, Faith DP, Häuser C, Joly CA, Kogure K, Larigauderie A, Magallón S, Moritz CC, Tillier S, Zardoya R, Prieur-Richard AH, Walther BA, Yahara T, Donoghue MJ (2010) Evolutionary biology in biodiversity science, conservation, and policy: a call to action. Evolution 64:1517-1528

Hendry AP, Kinnison MT, Heino M, Day T, Smith TB, Fitt G, Bergstrom CT, Oakeshott J, Jørgensen PS, Zalucki MP, Gilchrist G, Southerton S, Sih A, Strauss S, Denison RF, Carroll SP (2011) Evolutionary principles and their practical application. Evol Appl 4:159-183

Hewitt GM (2000) The genetic legacy of the quaternary ice ages. Nature 405:907-913

Hoekstra JM, Boucher TM, Ricketts TH, Roberts C (2005) Confronting a biome crisis: global disparities of habitat loss and protection. Ecol Lett 8:23-29

Huson DH, Bryant D (2006) Application of phylogenetic networks in evolutionary studies. Mol Biol Evol 23:254-267

Isaac NJB, Turvey ST, Collen B, Waterman C, Baillie JEM (2007) Mammals on the EDGE: conservation priorities based on threat and phylogeny. PLoS ONE 2:e296

Kadis C, Thanos CA, Laguna Lumbreras E (2013) Plant micro-reserves: from theory to practice. Experiences gained from EU LIFE and other related projects. Utopia Publishing, Athens

Kraft NJB, Baldwin BG, Ackerly DD (2010) Range size, taxon age and hotspots of neoendemism in the California flora. Divers Distrib 16:403-413

Ladle R, Whittaker RJ (2011) Conservation biogeography. Wiley, New York 
Laguna E, Deltoro VI, Pèrez-Botella J, Pèrez-Rovira P, Serra L, Olivares A, Fabregat C (2004) The role of small reserves in plant conservation in a region of high diversity in eastern Spain. Biol Conserv 119:421-426

Lefebvre T, Moncorps S (2010) Les espaces protégés français: une pluralité d'outils au service de la conservation de la biodiversité. Comité français de l'UICN, Paris

Lhotte A, Affre L, Saatkamp A (2014) Are there contrasted impacts of urbanization and land uses on population persistence? The case of Teucrium pseudochamaepitys, an endangered species in Southern France. Flora 209:484-490

Lopez L, Retuerto R, Roiloa S, Santiso X, Barreiro R (2015) A multi-faceted approach for assessing evolutionary significant conservation units in the endangered Omphalodes littoralis subsp. gallaecica (Boraginaceae). Perspect Plant Ecol Evol Syst 17:54-65

Lumbreras EL (2001) The micro-reserves as a tool for conservation of threatened plants in Europe. Nature and Environment series $\mathrm{n}^{\circ} 121$. Council of Europe, Strasbourg

Mace GM, Gittleman JL, Purvis A (2003) Preserving the tree of life. Science 300:1707-1709

Malaney J, Cook JA (2013) Using biogeographical history to inform conservation: the case of Preble' s meadow jumping mouse. Mol Ecol 22:6000-6017

Margules CR, Pressey RL (2000) Systematic conservation planning. Nature 405:243-253

Mayol M, Palau C, Rosselló JA, González-Martínez SC, Molins A, Riba M (2012) Patterns of genetic variability and habitat occupancy in Crepis triasii (Asteraceae) at different spatial scales: Insights on evolutionary processes leading to diversification in continental islands. Ann Bot 109:429-441

McCleery RA, Moorman C, Peterson MN (2014) Urban wildlife conservation. Theory and practice. Springer, Berlin

Mcdonald RI, Kareiva P, Forman RTT (2008) The implications of current and future urbanization for global protected areas and biodiversity conservation. Biol Conserv 141:1695-1703

McKinney (2002) Urbanization, biodiversity, and conservation. Bioscience 52:883-890

Médail F, Diadema K (2006) Biodiversité végétale méditerranéenne et anthropisation: approches macro et micro-régionales. Ann Georgr 651:618-640

Médail F, Diadema K (2009) Glacial refugia influence plant diversity patterns in the Mediterranean Basin. J Biogeogr 36(7):1333-1345

Médail F, Verlaque R (1997) Ecological characteristics and rarity of endemic plants from southeast France and Corsica: implications for biodiversity conservation. Biol Conserv 80(3):269-281

Meyer WB, Turner BL II (1992) Human population growth and global land-use. Annu Rev Ecol Syst 23:39-61

Migliore J, Baumel A, Juin M, Diadema K, Hugot L, Verlaque R, Médail F (2011) Genetic diversity and structure of a Mediterranean endemic plant in Corsica (Mercurialis corsica, Euphorbiaceae). Popul Ecol 53:573-586

Migliore J, Baumel A, Juin M, Médail F (2012) From Mediterranean shores to central Saharan mountains: key phylogeographical insights from the genus Myrtus. J Biogeogr 39:942-956

Molins A, Bacchetta G, Rosato M, Rosselló JA, Mayol M (2011) Molecular phylogeography of Thymus herba-barona (Lamiaceae): insight into the evolutionary history of the flora of the western Mediterranean islands. Taxon 60:1295-1305

Moritz CC (1994) Defining "Evolutionarily Significant Units” for conservation. TREE 9:373-375

Moritz CC (2002) Strategies to protect biological diversity and the evolutionary processes that sustain it. Syst Biol 51:238-254

Moritz CC, Potter S (2013) The importance of an evolutionary perspective in conservation policy planning. Mol Ecol 22:5969-5971

Newton AC, Allnutt TR, Lowe AJ, Ennos RA (1999) Molecular phylogeography, intraspecific variation and the conservation of tree species. TREE 14:140-145

Noble V, Diadema K (2011) La flore des Alpes-Maritimes et de la Principauté de Monaco: originalité et diversité. Naturalia Publications, Turriers

Olivier L, Galland JP, Maurin H, Roux JP (1995) Livre rouge de la flore menacée de France. Tome 1: Espèces prioritaires. Collection Muséum national d'Histoire naturelle, Conservatoire botanique national de Porquerolle, Hyères

Otero I, Marull J, Tello E, Diana GL, Pons M, Coll F, Boada M (2015) Land abandonment, landscape, and biodiversity: questioning the restorative character of the forest transition in the Mediterranean. Ecol Soc 20:7

Pärtel M, Kalamees R, Ulle R, Tuvi EL, Roosaluste E, Vellak A, Zobel M (2005) Grouping and prioritization of vascular plant species for conservation: combining natural rarity and management need. Biol Conserv 123:271-278 
Pouget M (2014) Comment préserver l'héritage évolutif singulier des végétaux endémiques méditerranéens. $\mathrm{PhD}$ Thesis, Aix-Marseille Université, Marseille

Pouget M, Youssef S, Migliore J, Juin M, Médail F, Baumel A (2013) Phylogeography sheds light on the central-marginal hypothesis in a Mediterranean narrow endemic plant. Ann Bot 112:1409-1420

QGIS Development Team (2015) QGIS Geographic Information System. Open Source Geospatial Foundation. http://qgis.osgeo.org

R Development Core Team (2015) R: a language and environment for statistical computing. R Foundation for Statistical Computing, Vienna

Rosauer D, Laffan SW, Crisp MD, Donnellan SC, Cook LG (2009) Phylogenetic endemism: a new approach for identifying geographical concentrations of evolutionary history. Mol Ecol 18:4061-4072

Ryder OA (1986) Species conservation and systematics: the dilemma of subspecies. Trends Ecol Evol 1:9-10

Sanz AS, Fernandez C, Mouillot F, Ferrat L, Istria D, Pasqualini V (2013) Long-term forest dynamics and land-Use abandonment in the Mediterranean mountains, Corsica, France. Ecol Soc 18:38

Sauquet H, Weston PH, Anderson CL, Barker NP, Cantrill DJ, Mast AR, Savolainen V (2009) Contrasted patterns of hyperdiversification in Mediterranean hotspots. Proc Natl Acad Sci USA 106:221-225

Schaal BA, Hayworth DA, Olsen KM, Rauscher JT, Smith WA (1998) Phylogeographic studies in plants: problems and prospects. Mol Ecol 7:465-474

SILENE-Flore: Conservatoire Botanique National Méditerranéen and Conservatoire Botanique National Alpin (Admin.). AAAA. SILENE-Flore [en ligne]. http://flore.silene.eu (consulté le 10/06/2014)

SILENE-Habitats: Conservatoire Botanique National Méditerranéen and Conservatoire Botanique National Alpin (Admin.). AAAA. SILENE-Habitats [en ligne]. http://habitats.silene.eu (consulté le 16/10/2013)

Sirami C, Nespoulous A, Cheylan J-P, Marty P, Hvenegaard GT, Geniez P, Schatz B, Martin JL (2010) Long-term anthropogenic and ecological dynamics of a Mediterranean landscape: impacts on multiple taxa. Landsc Urban Plan 96:214-223

Tatoni T, Roche P, Médail F, Barbero M (2004) The impact of changes in land use on ecological patterns in Provence (Mediterranean France). In: Mazzoleni S, Di Pascale G, Di Martino P, Rego F, Mulligan M (eds) Recent dynamics of Mediterranean vegetation and landscape. Wiley, London

Thompson JD, Lavergne S, Affre L, Gaudeul M, Debussche M (2005) Ecological differentiation of mediterranean endemic plants. Taxon 54(4):967

Underwood EC, Viers JH, Klausmeyer KR, Cox RL, Shaw MR (2009) Threats and biodiversity in the mediterranean biome. Divers Distrib 15:188-197

Vogler AP, Desalle R (1994) Diagnosing units of conservation management. Conserv Biol 8:354-363

Waples RS (1991) Pacific Salmon, Oncorhynchus spp., and the definition of "Species" under the Endangered Species Act. Mar Fish Rev 53:11-22

Westergaard KB, Alsos IG, Popp M, Engelskjøn T, Flatberg KI, Brochmann C (2011) Glacial survival may matter after all: nunatak signatures in the rare European populations of two west-arctic species. Mol Ecol 20:376-393

Wilcove DS, Rothstein D, Dubow J, Phillips A, Losos E (1998) Threats to imperiled quantifying species in the United States. Bioscience 48:607-615 